OPEN ACCESS

Edited by: Stephen J. Pandol, Cedars-Sinai Medical Center, United States

Reviewed by: Caroline A. Cobine, University of Nevada, Reno, United States Shin Hamada,

Tohoku University, Japan

${ }^{*}$ Correspondence: Lijian Shao Ishao@ncu.edu.cn

Specialty section: This article was submitted to Gastrointestinal Sciences, a section of the journal Frontiers in Physiology

Received: 25 April 2021 Accepted: 22 June 2021 Published: 14 July 2021

Citation:

Duan H, Cai X, Luan Y, Yang S, Yang J, Dong $H$, Zeng $H$ and Shao $L$ (2021) Regulation of the Autonomic

Nervous System on Intestine.

Front. Physiol. 12:700129. doi: 10.3389/fphys.2021.700129

\section{Regulation of the Autonomic Nervous System on Intestine}

\author{
Hongyi Duan', Xueqin Cai', Yingying Luan', Shuo Yang',2, Juan Yang1,2, Hui Dong',3, \\ Huihong Zeng ${ }^{1,3}$ and Lijian Shao ${ }^{1,2,3 *}$ \\ ${ }^{1}$ Medical College of Nanchang University, Nanchang, China, ${ }^{2}$ Jiangxi Provincial Key Laboratory of Preventive Medicine, \\ Nanchang University, Nanchang, China, ${ }^{3}$ Jiangxi Provincial Key Laboratory of Interdisciplinary Science, Nanchang University, \\ Nanchang, China
}

Intestine is composed of various types of cells including absorptive epithelial cells, goblet cells, endocrine cells, Paneth cells, immunological cells, and so on, which play digestion, absorption, neuroendocrine, immunological function. Intestine is innervated with extrinsic autonomic nerves and intrinsic enteric nerves. The neurotransmitters and counterpart receptors are widely distributed in the different intestinal cells. Intestinal autonomic nerve system includes sympathetic and parasympathetic nervous systems, which regulate cellular proliferation and function in intestine under physiological and pathophysiological conditions. Presently, distribution and functional characteristics of autonomic nervous system in intestine were reviewed. How autonomic nervous system regulates intestinal cell proliferation was discussed. Function of autonomic nervous system on intestinal diseases was extensively reviewed. It might be helpful to properly manipulate autonomic nervous system during treating different intestinal diseases.

Keywords: intestine, autonomic nerve system, enteric nervous system, cellular proliferation, intestinal disease

\section{INTRODUCTION}

Innervation of the gastrointestinal tract includes extrinsic autonomic nerve system (ANS) and intrinsic enteric nervous system (ENS). The related neurotransmitter receptors are widely distributed in various intestinal cells. The intestinal sympathetic nerve originates from the anterior vertebral ganglia and innervates the different segments of the intestine (Figure 1). The property benefits to balance various homeostasis functions, such as controlling vascular tension, regulating the activity of the smooth muscle in the intestine, reducing the secretion of the mucosa (Browning and Travagli, 2014). Intestinal vagus regulates motility in the small intestine and colon, and controls gastric motility, and secretion (Costa et al., 2000; Bohorquez et al., 2015). The regulation of gastrointestinal sympathetic and parasympathetic pathways plays crucial roles on intestinal mucosal regeneration and the immune response. Sympathetic and parasympathetic fibers entering the intestinal wall form synaptic connections with the myenteric ganglia, smooth muscle, and mucosa (Costa et al., 2000; Bohorquez et al., 2015). Sympathetic nervous system (SNS) and parasympathetic nervous system (PNS) can function independently on the gut. Nerve endings from SNS are concentrated densely at the base of the crypt where intestinal stem cells (ISCs) are located (Norberg, 1964; Gabella and Costa, 1968), while PNS nerves and intestinal epithelial cells (IECs) are directly synapsed (Bohorquez et al., 2015). The effects of norepinephrine NE on enteric epithelial cells can be transduced by SNS signaling. It is possible that SNS and PNS directly control IECs. Although both PNS and ENS use acetylcholine (Ach) as a neurotransmitter, PNS denervation 
with intact ENS circuits negatively affects intestinal epithelial proliferation (Mcconalogue and Furness, 1994) and inflammation (Ghia et al., 2006, 2007). These data suggest that PNS can regulate intestinal mucosal regeneration and inflammation.

The autonomic nervous system can function through intestinal stromal cells and immune cells, which include macrophages (M申s), lymphocytes, mast cells (MCs), dendritic cells (DCs), and innate lymphoid cells (ILCs) in intestine. They either form synapses with autonomic nerves or express the neurotransmitter receptors, which have positive or negative effects on the physiological and pathological states of the gut (Ghia et al., 2006, 2007). It has been documented that the autonomic nervous system directly or indirectly regulates the physiological activity of IEC, stromal cells, enteric nerves, and intestinal immune cells. In the present review, we will discuss the regulation of autonomic nervous system on intestine under physiological and pathological settings, which will provide new strategies to treat various intestinal diseases.

\section{AUTONOMIC NERVOUS SYSTEM REGULATES INTESTINAL EPITHELIAL CELL PROLIFERATION}

To maintain appropriate tissue function, IECs are rapidly renewed, a process driven by ISCs that proliferate in crypts (Barker et al., 2007). Stem cells at the bottom of the crypt divide to produce transit-amplifying (TA) progenitor cells. Once they reach the base of the villi, these cells complete differentiation and perform their maturation. Ample evidence has shown that ANS is involved in the proliferation of epithelial cells and affects intestinal homeostasis.

\section{Effects of Autonomic Neurotransmitters and Receptors on the Intestinal Epithelial Cell Proliferation}

Sympathetic nervous system and PNS nerve endings are adjacent to or directly synapse with IECs (Gabella and Costa, 1968; Bohorquez et al., 2015). It has demonstrated that IECs express multiple autonomic neurotransmitter receptors [M1-5 (Greig and Cowles, 2017), $\alpha-2 \mathrm{~A}$ (Paris et al., 1990; Valet et al., 1993; Schaak et al., 2000), $\beta$-2 (Zeng et al., 2020), Table 1], which are involved in the proliferation regulation of intestinal epithelium. Researchers reported that cholinergic neurons directly control the ISCs (Lundgren et al., 2011). Greig and Cowles (2017) found that the depth of ileal crypts was increased in all five knockout mice lacking muscarinic receptor subtypes (M1KO$\mathrm{M} 5 \mathrm{KO}$ ) than that in wild-type mice. The ileal crypt proliferation index was significantly increased in four knockout mice except for M4KO mice. Schaak et al. (2000) confirmed that upregulation of $\alpha 2 \mathrm{~A}$ epinephrine receptor increased proliferation of intestinal $\mathrm{CaCo} 2$ epithelial cells. It is noteworthy that SNS-associated $\alpha 2 \mathrm{~A}$ receptor and PNS-associated ACh receptor subtypes $\mathrm{M} 1$ and M3 are elevated in ISCs when compared to those in Paneth cells (Davis et al., 2018). M3 and M5 muscarinic receptors exist on the ISCs (Lundgren et al., 2011). They may be important targets for subsequent effects on the proliferation and differentiation of ISCs.

Additionally, it is well known that Paneth cells and stromal cells, as the content of highly structured niche where the ISCs reside, are the sources of Wnts and R-spondins for ISCs. Particularly, stromal cells product Wnts, R-spondin 1 and R-spondin 3 to activate Wnt pathway in ISCs, which can maintain stem cells and prevent acute bowel injury (Greicius et al., 2018; Wu et al., 2021). It has been demonstrated that nerve system regulates IECs proliferation and differentiation

TABLE 1 | ANS regulates intestinal cell proliferation

\begin{tabular}{|c|c|c|c|c|}
\hline Populations & Conditions & $\begin{array}{l}\text { Autonomic } \\
\text { nerve } \\
\text { receptors }\end{array}$ & Functions & References \\
\hline \multirow[t]{7}{*}{$\begin{array}{l}\text { Intestinal } \\
\text { epithelial cells } \\
\text { (IECs) }\end{array}$} & M1KO-M5KO & $\begin{array}{l}\text { Knockout } \\
\text { M1-5 } \\
\text { muscarinic } \\
\text { receptors }\end{array}$ & $\begin{array}{l}\text { Increase } \\
\text { depth of ileal } \\
\text { crypts, } \\
\text { increase } \\
\text { proliferation }\end{array}$ & $\begin{array}{l}\text { Greig and } \\
\text { Cowles } \\
(2017)\end{array}$ \\
\hline & $\begin{array}{l}\text { Cholinergic } \\
\text { agonist } \\
\text { carbachol }\end{array}$ & $\begin{array}{l}\text { Activate } \\
\text { mAChR }\end{array}$ & $\begin{array}{l}\text { Reduce } \\
\text { proliferation }\end{array}$ & $\begin{array}{l}\text { Takahashi } \\
\text { et al. (2014) }\end{array}$ \\
\hline & $\begin{array}{l}\text { CaCo2 cell } \\
\text { transfected } \\
\text { with } \alpha 2 \mathrm{~A} \\
\text { epinephrine } \\
\text { receptor }\end{array}$ & $\begin{array}{l}\text { Activate } \\
\alpha 2 \mathrm{~A} \\
\text { adrenergic } \\
\text { receptor }\end{array}$ & $\begin{array}{l}\text { Increase } \\
\text { proliferation }\end{array}$ & $\begin{array}{l}\text { Schaak et al. } \\
(2000)\end{array}$ \\
\hline & $\begin{array}{l}\text { a2 adrenergic } \\
\text { agonist } \\
\text { clonidine }\end{array}$ & $\begin{array}{l}\text { Activate } \alpha 2 \\
\text { adrenergic } \\
\text { receptor }\end{array}$ & $\begin{array}{l}\text { Increase } \\
\text { proliferation }\end{array}$ & $\begin{array}{l}\text { Kennedy } \\
\text { et al. (1983) }\end{array}$ \\
\hline & $\begin{array}{l}\alpha \text { adrenergic } \\
\text { antagonist } \\
\text { phentolamine }\end{array}$ & $\begin{array}{l}\text { Inhibit } \alpha \\
\text { adrenergic } \\
\text { receptor }\end{array}$ & $\begin{array}{l}\text { Reduce } \\
\text { proliferation }\end{array}$ & $\begin{array}{l}\text { Kennedy } \\
\text { et al. (1983) }\end{array}$ \\
\hline & $\begin{array}{l}\alpha 1 \text { adrenergic } \\
\text { agonist } \\
\text { phenylephrine } \\
\beta \text { adrenergic } \\
\text { agonist } \\
\text { isoprenaline }\end{array}$ & $\begin{array}{l}\text { Inhibit } \alpha-1 \\
\text { and } \beta \\
\text { adrenergic } \\
\text { receptors }\end{array}$ & $\begin{array}{l}\text { Inhibit } \\
\text { proliferation }\end{array}$ & $\begin{array}{l}\text { Kennedy } \\
\text { et al. (1983) }\end{array}$ \\
\hline & $\begin{array}{l}\mathrm{NE} \text { and } \mathrm{ACH} \\
\text { treatment }\end{array}$ & $\begin{array}{l}\text { Activate } \\
\text { adrenergic } \\
\text { receptor }\end{array}$ & $\begin{array}{l}\text { Reduce the } \\
\text { expression of } \\
\text { the cyclin D1 }\end{array}$ & $\begin{array}{l}\text { Davis et al. } \\
\text { (2018) }\end{array}$ \\
\hline \multirow[t]{4}{*}{$\begin{array}{l}\text { Intestinal } \\
\text { stem cells } \\
\text { (ISCs) }\end{array}$} & $\begin{array}{l}\text { Mouse small } \\
\text { intestine }\end{array}$ & $\begin{array}{l}\mathrm{M} 1,3 \\
\text { muscarinic } \\
\text { receptors }\end{array}$ & $\begin{array}{l}\text { Specifically } \\
\text { increase in } \\
\text { ISCs relative } \\
\text { to villus cells } \\
\text { or Paneth cells }\end{array}$ & $\begin{array}{l}\text { Davis et al. } \\
\text { (2018) }\end{array}$ \\
\hline & $\begin{array}{l}\text { Rat small } \\
\text { intestine }\end{array}$ & $\begin{array}{l}\text { M3,5 } \\
\text { muscarinic } \\
\text { receptors }\end{array}$ & $\begin{array}{l}\text { Expression in } \\
\text { ISCs }\end{array}$ & $\begin{array}{l}\text { Lundgren } \\
\text { et al. (2011) }\end{array}$ \\
\hline & $\begin{array}{l}\text { Mouse small } \\
\text { intestine }\end{array}$ & $\begin{array}{l}\alpha 2 \mathrm{~A} \\
\text { adrenergic } \\
\text { receptor }\end{array}$ & $\begin{array}{l}\text { Specifically } \\
\text { increase in } \\
\text { ISCs relative } \\
\text { to villus cells } \\
\text { or Paneth cells }\end{array}$ & $\begin{array}{l}\text { Davis et al. } \\
\text { (2018) }\end{array}$ \\
\hline & $\begin{array}{l}\text { ISO treatment } \\
\text { after } \\
\text { chemotherapy }\end{array}$ & $\begin{array}{l}\text { Activate } \beta 2 \\
\text { adrenergic } \\
\text { receptor }\end{array}$ & $\begin{array}{l}\text { Ameliorate the } \\
\text { reduction in } \\
\text { ISCs during } \\
\text { chemotherapy }\end{array}$ & $\begin{array}{l}\text { Zeng et al. } \\
\text { (2020) }\end{array}$ \\
\hline
\end{tabular}




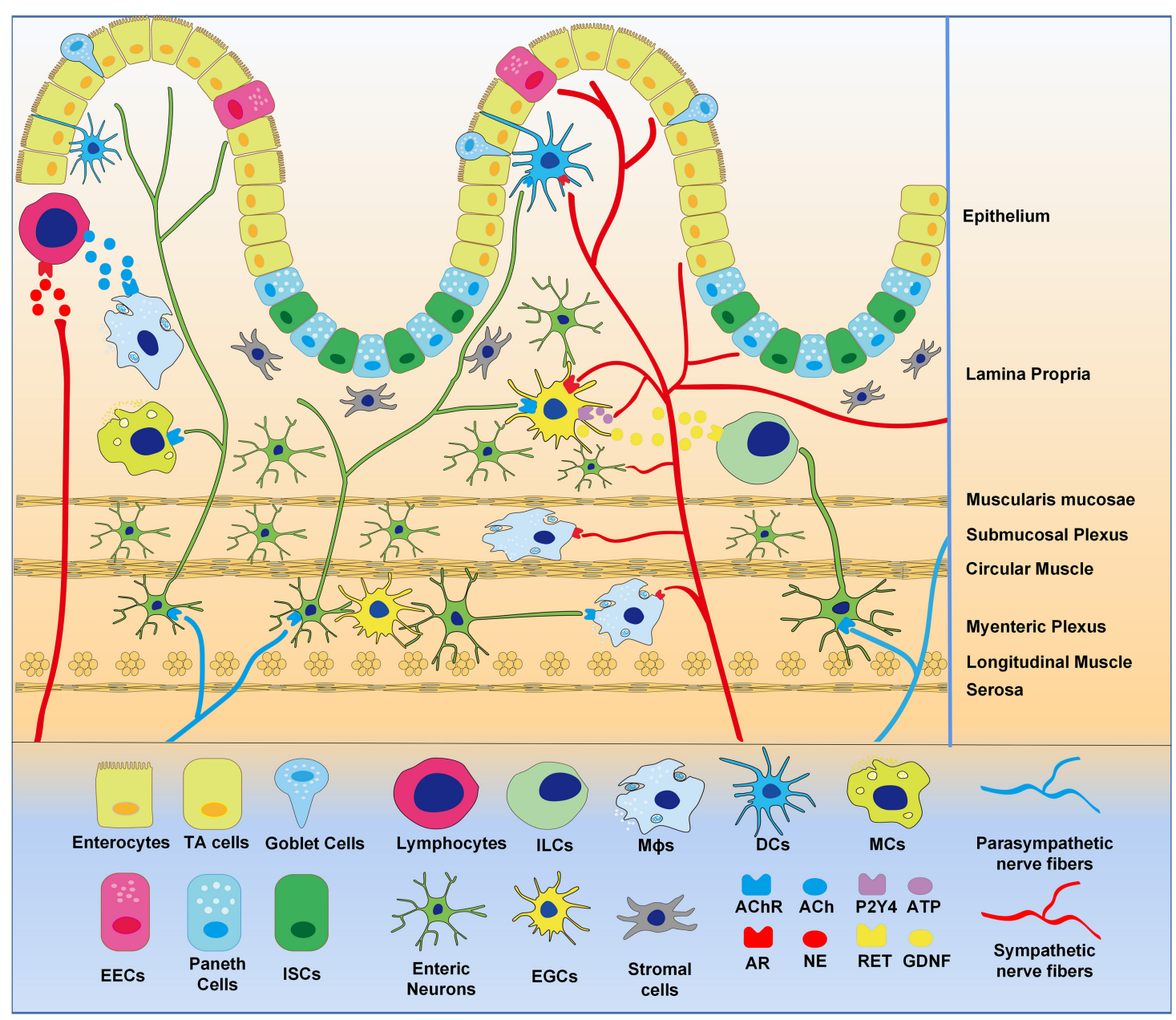

FIGURE 1 | Distribution of intestinal neural network. Extrinsic sympathetic and parasympathetic nerve fibers enter the whole layer of the intestinal wall to form complex neural networks with intrinsic enteric nervous and EGCs that innervate gastrointestinal epithelial and immune cells. Epitheliums are differentiated from intestinal stem cells, demonstrating enterocytes, endocrine cells, goblet cells, and Paneth cells. Intestinal stromal cells and various immune cells reside in the intestinal wall, the later including macrophages (M申s), lymphocytes, mast cells (MCs), dendritic cells (DCs), and innate lymphoid cells (ILCs). Intestinal neural networks regulate intestinal cells, via neurotransmitters (ACh, NE, ATP etc.), neurotrophic factors (GDNF etc.) and receptors (AChR, AR, P2Y4, RET etc.).

through Paneth cells and stromal cells. For instance, acetylcholine receptor (AChR) activation regulates the function of Paneth cells (Satoh, 1988; Satoh et al., 1992), and vagal innervation is required for the function of stromal cells (Olivier et al., 2016).

Exogenous administration of primary autonomic neurotransmitters alters intestinal cell proliferation (Table 1). Alpha-2 agonists increased epithelial proliferation in the jejunum and colon in mice and rats, while phentolamine therapy (alphaadrenergic antagonists) reduced the numbers of cells in crypts of the jejunum in rats. In contrast, $\alpha-1$ and beta-adrenergic agonists inhibit cell proliferation in intestine (Tutton, 1975; Kennedy et al., 1983). These methods do not promote or inhibit the proliferation of colon cancer cells (Tutton and Barkla, 1977). Recent studies have demonstrated that $\mathrm{NE}$ and $\mathrm{ACH}$ regulate the proliferation of intestinal organs by decreasing expression of cyclin D1 (Davis et al., 2018). ACh agonists reduce the proliferation of intestinal epithelial organs (Takahashi et al.,
2014). Our group showed that $\beta 2$ receptor co-localized with Olfm $4^{+}$ISCs in crypts. Isoproterenol treatment ameliorates the reduction in the numbers of ISCs during chemotherapy (Zeng et al., 2020). This is mediated by activating $\beta 2$ adrenergic receptor on ISCs (Zeng et al., 2020). Function of sympathetic nerves has also been demonstrated using genetic approaches on stem cells, such as hematopoietic stem cells (Lucas et al., 2013) and hair follicle stem cells (Shwartz et al., 2020). These data indicate that autonomic nervous system plays an important role in intestinal mucosal regeneration under pathological conditions. Autonomic co-transmitters bind to receptors on ISCs to affect cellular proliferation. For example, vasoactive peptides (Khedr et al., 2018; Iwasaki et al., 2019), neuropeptides Y (Erlinge et al., 1994; Oben et al., 2003) and adenosine triphosphate (ATP) (Erlinge et al., 1993, 1994) can regulate intestinal cell proliferation. These studies support ANS can regulate ISC proliferation and tissue regeneration through neurotransmitters and their receptors. 


\section{Effects of Autonomic Nerve Denervation on the Proliferation of Intestinal Epithelial Cells}

Surgical or chemical ablation of the branches of ANS, the sympathetic or parasympathetic nerves, causes the loss of autonomic neurotransmitter sources and alters the proliferation of intestinal crypt cells (Tutton and Helme, 1974; Musso et al., 1975; Tsibulevskii and Orlova, 1976; Lachat and Goncalves, 1978; Kennedy et al., 1983; Callaghan, 1991). The direction of proliferation changes is based on the time after denervation (Davis et al., 2017). After SNS or PNS denervation, proliferation was shown to increase (Tsibulevskii and Orlova, 1976; Lachat and Goncalves, 1978; Callaghan, 1991) and decrease (Tutton and Helme, 1974; Musso et al., 1975; Lachat and Goncalves, 1978; Kennedy et al., 1983; Callaghan, 1991) at different time points. Several studies have shown that after the removal of SNS or PNS, the gut returns to normal proliferative levels (Musso et al., 1975; Lachat and Goncalves, 1978; Davis et al., 2017), which is satisfactory information for patients who need autonomic nerve denervation. Intestinal epithelial proliferation was reduced during first 3 days in rat intestines after PNS denervation (Musso et al., 1975; Lachat and Goncalves, 1978), while the cellular proliferation in jejunum (Tsibulevskii and Orlova, 1976; Callaghan, 1991) and ileum (Callaghan, 1991) was back to normal after 7 days under PNS denervation. Previous studies have detected indirect effects on proliferation due to changes in food intake, inflammation or other factors that alter the proliferation of IECs following denervation surgery (Dailey, 2014; Slater et al., 2017; Goldstein et al., 2021). For instance, neurons expressing agouti-related protein (AgRP) are a highly active group of hypothalamuses during hunger that significantly promote eating behavior, and direct injection of nutrients into the gut leads to a sustained and rapid reduction in AgRP neuron activity (Aponte et al., 2011). Subdiaphragmatic vagotomies reducated the effect of fat on AgRP neurons activity, changing the certain food intake (Goldstein et al., 2021).

The effects of SNS denervation on intestinal epithelial proliferation seem to be related to the degree of denervation induced by different denervation techniques. Chemical denervation (6-OHDA) of sympathetic nerves resulted in a long-term reduction in proliferation (Tutton and Helme, 1974; Kennedy et al., 1983), along with a reduction in cryptic ISCs (Zeng et al., 2020). However, more precise denervation has a short-term effect in the jejunum (Tutton and Helme, 1974). Therefore, the intestinal autonomic nervous system can directly affect the proliferation of IECs at the early phase after denervation.

\section{IMMUNE REGULATION OF INTESTINE BY ANS SYSTEM}

\section{Intestinal Epithelial Cells (IECs)}

The intestinal physical barrier was formed by IECs and the tight junction between IECs, which is the largest exchange surface between the body and the external environment. Once the intestinal epithelial barrier function is disrupted or maladjusted, it will cause bacterial translocation, leading to a severe blow to the body's multiple organs and systems with sepsis and even death (Magnotti and Deitch, 2005). Autonomic nerve can change the barrier function in physiological and pathological states. Extradural intrathoracic lidocaine can block sympathetic nerves, inhibiting the activation of intestinal macrophages and the destruction of the intestinal mucosal barrier in endotoxemia mice (Schaper et al., 2013). Vagus nerve stimulation (VNS) reduces intestinal permeability in lipopolysaccharides (LPS)induced endotoxemia mice and counteracted tight junction damage (Zhou et al., 2013).

The effects of parasympathetic neurotransmitters and receptors on barrier function have been demonstrated. Acetylcholine (ACh) mediates the increased colonic permeability in stress-induced barrier dysfunction in rats, while muscarinic receptor antagonists blocked the increased colonic permeability in the stressed conditions (Gareau et al., 2007). M3 receptor activation increases macromolecule transportation in mouse and human IECs (Cameron and Perdue, 2007). However, the protective effect of muscarinic receptors on the maintenance of the intestinal epithelial barrier was observed under different conditions. It was demonstrated that activation of muscarinic receptors in the monolayer of $\mathrm{CaCO}-2$ epithelial cells counteracts interleukin (IL)- $1 \beta$-induced barrier disruption by reducing myosin light-chain kinase protein translation (Schutz et al., 2015). Activation of muscarinic receptor with bethanechol causes the cytokine exposure of epithelial cells and a decrease in occludin expression (Slater et al., 2017). Similarly, activation of M1 or M3 muscarinic receptors counteracts the destruction of the single layer of intestinal epithelial barrier induced by inflammatory mediators (Khan et al., 2014; Uwada et al., 2017). Besides, nicotine receptors affect the maintenance of the integrity of the intestinal epithelial barrier, particularly the $\alpha 7$ nicotinic acetylcholine receptors ( $\alpha 7$-nAchRs). The receptor has been shown to counteract changes in rat tight junction protein and increase intestinal permeability induced by LPS (Zhang and Li, 2012; Zhou et al., 2013). Similar findings have been observed in models of impaired barrier integrity induced by burns, in which nicotine injections prevent the reduction of burn-induced occludin and zonula occludens (ZO)-1 to maintain intestinal barrier function (Costantini et al., 2012). AChR activation mediated the function of Paneth cells (Satoh, 1988; Satoh et al., 1992), goblet cells (Gustafsson et al., 2012; Birchenough et al., 2016), and enteroendocrine cell (Anini and Brubaker, 2003), such as degranulation and secretion. AChR activation results in increased antigen presentation of goblet cells (Mcdole et al., 2012). Therefore, parasympathetic nerve plays an irreplaceable role in the regulation of intestinal barrier.

\section{Enteric Nervous System (ENS)}

Enteric nervous system has been called "the second brain," which be allowed to regulate intestinal behavior without central nervous system input. Although the ENS can function independently, autonomic nerve fibers entering the intestinal wall can form synaptic connections with part of the intestinal ganglion cells (Costa et al., 2000; Figure 1). Extrinsic connectivity from the 
CNS to the ENS is composed of sympathetic and parasympathetic nerve fibers. The ENS can regulate intestinal immunity through the synapses with enteric neuron.

Enteroglial cells (EGCs), as support cells of intestinal neurons, form a communication network in the intestinal wall via secreting neuron-related factors, regulating intestinal immunity and epithelial cell proliferation (Ochoa-Cortes et al., 2016). Researchers have recognized the role of autonomic innervation in EGCs (Figure 1). Gulbransen and Sharkey (2009) and Gulbransen et al. (2010) demonstrated that sympathetic pathways were involved in the regulation of EGCs. Sympathetic fibers activate EGCs via releasing ATP through purinergic P2Y4 receptors on EGCs. Nasser et al. (2006) found that EGCs express alpha 2 adrenergic receptor despite the functional significance of the receptor has not been assessed. The activation of EGCs attenuates the interruption of intestinal epithelial barrier through VNS (Costantini et al., 2010). EGCs secret nitric oxide, which takes part in the maintenance of intestinal homeostasis and the regulation of ion transportation in epithelial cells (Maceachern et al., 2011).

\section{Stromal Cells}

Intestinal stromal cells, as part of stem cell niche, are also called intestinal myofibroblasts. Its important role in the IECs proliferation and differentiation has been described above. It has been shown that stromal cells express a broad range of neurotransmitter receptors in a variety of different tissues and have the ability to respond to various neurotransmitters. Thus, it is plausible that ANS innervation of the gut may be able to directly or indirectly affect intestinal stromal cells (Wheatley et al., 1992; Obara et al., 2000; Pereira et al., 2003; MéndezFerrer et al., 2010; Figure 1). It has been shown that colonic stromal cells were activated during acute inflammation induced by dextran sulphate sodium (DSS). Upregulation of chemokine CXCL13 and CCL20 expression in stromal cells was blocked when the extrinsic vagal innervation was blocked, implying a sense and response function of the vagus nerve (Olivier et al., 2016). Furthermore, transplantation of mesenchymal stem cells (MSCs), a hot research area, can promote de novo functional enteric nerve regeneration via glial cell-derived neurotrophic factor (GDNF), but not through direct trans-differentiation (Lin et al., 2015). These studies have revealed the possibility of bidirectional regulation of stromal cells and ANS.

\section{Macrophages (M $\phi s)$}

Macrophages in the gastrointestinal tract are a highly heterogeneous population and able to sense and adapt to environmental signals (Lavin et al., 2014; Okabe and Medzhitov, 2014). Morphological studies have shown that both external autonomic nerves and intrinsic neural pathways are synaptic with muscular M $\phi s$ (Ghia et al., 2007; Phillips and Powley, 2012; Figure 1). Cailotto et al. (2014) provided evidence that vagal efferent fibers are in contact with cholinergic neurons in the myenteric layer, while myenteric cholinergic neurons have nerve endings that are close to resident M $\phi$ s expressing $\alpha 7-n A C h R$. The $\alpha 7-n A C h R$ agonist, 5-hydroxytryptamine 4 receptor (5-HT4R) agonist and VNS activate the $\alpha 7-\mathrm{nAChR}$ receptor on $\mathrm{M} \phi$ s to improve gastric emptying and intestinal inflammation (de Jonge et al., 2005; The et al., 2007; Tsuchida et al., 2011). The vagal efferent fibers preferentially interact with nNOS, VIP and ChAT enteric neurons within the gut muscular rather than M $\phi$ s. These nNOS, VIP and ChAT positive neuronal fibers are closely contacted with M $\phi$ s (Cailotto et al., 2014), which can modulate intestinal M $\phi$ s to produce anti-inflammatory effects, such as promoting the production of IL-10 and down-regulating the expression of iNOS in macrophages (Delgado et al., 1999). Vagus nerve activity augments intestinal macrophage phagocytosis while inhibiting immune reactivity via $\alpha 4 \beta 2 \mathrm{nAChR}$ (van der Zanden et al., 2009). Extrinsic sympathetic neurons innervating the gut muscularis activate the $\beta 2$ adrenergic receptors on muscularis macrophages, enhancing tissue-protective programs upon luminal bacterial infection (Gabanyi et al., 2016). Therefore, M $\phi$ s are regulated by a complex set of neurons, including indirect vagal-mediated regulation, and direct regulation by the sympathetic pathway (Matteoli et al., 2014), which help to limit excessive tissue damage and inflammatory response. Therefore, $\mathrm{M} \phi$ s participate in an anti-inflammatory pathway mediated by sympathetic and parasympathetic pathways.

\section{Lymphocytes}

Lymphocytes are the primary executor of the immune system in the body. Recent findings indicate that the PNS regulates the balance between different types of lymphocytes in the intestine (Figure 1). Morishita et al. (2015) demonstrated that VNS in the trauma/hemorrhagic shock model increased the Treg/Th37 ratio in the mesenteric lymph nodes after damage, which promoted tolerance to inflammation. A suppressive effect of nicotine on B-cell activation has been reported, which is mediated by $\alpha 2, \alpha 4$, and $\beta 2$ subunits of nAChR (Skok et al., 2005). These data indicate that parasympathetic innervation protects against immune/inflammatory responses. Vagotomy inhibited the activity of Treg cells, which results in antigen tolerance impairment, accelerating the severity of colitis (Di Giovangiulio et al., 2016). The hepatic vagal afferent nerve is responsible for the indirect sensory intestinal microenvironment and transmits signal input to the brainstem solitary tract nucleus, eventually efferent to the vagus nerve and enteric neurons. The pathway maintains peripheral regulatory $\mathrm{T}$ cells via $\mathrm{AChR}$ in intestinal antigen-presenting cells (Teratani et al., 2020).

The adrenergic neuronal pathway has been shown to have direct and indirect effects on the activity of Treg cells. All primary and secondary lymphoid organs receive sympathetic input from post-ganglionic sympathetic fibers, such as spleen, lymphoid nodes, thymus and bone marrow (Felten et al., 1985; Nance and Burns, 1989; Bellinger et al., 1992). Activation of sympathetic nerve $\beta 2$ adrenergic receptor signal impairs the differentiation and function of Th1 cells and reduces the production of IL-12, TNF- $\alpha$, and IFN- $\gamma$ (Sanders et al., 1997; Elenkov et al., 2000). Sympathetic fibers activate the $\beta 2$ adrenaline receptor to enhance the immunosuppressive activity of Treg cells (Guereschi et al., 2013). Activation of Treg cells has been demonstrated to be mediated indirectly through DCs (Nijhuis et al., 2014). Lymphocytes play a vital role in the 
cholinergic anti-inflammatory pathway (CAIP) (Figure 2), which was validated by the observation that the CAIP does not occur in nude mice lacking $\mathrm{T}$ cells (Rosas-Ballina et al., 2011). The CAIP depends on norepinephrine produced by splenic sympathetic fibers (Rosas-Ballina et al., 2008), which can lead $\mathrm{ChAT}^{+} \mathrm{T}$ cell to release acetylcholine through $\beta 2$ receptor (Rosas-Ballina et al., 2011; Vida et al., 2011). Acetylcholine from lymphocytes binds to the $\alpha 7-n A C h R$ on the bone marrow-derived non-T cells along with inhibiting LPS-mediated cytokine production (Olofsson et al., 2012). Therefore, intestinal sympathetic innervation may play an important role in Treg cells by activating the $\beta 2$ adrenal receptor to maintain the intestinal tolerance response mediated by immunosuppression of Treg cells. These data suggest that both cholinergic and adrenergic pathways are involved in lymphocyte proliferation and function in the process of intestinal inflammation.

\section{Others}

In addition to the above-mentioned cells, MCs, DCs, and ILCs could be regulated by ANS (Figure 1). MCs are a type of intestinal immune cells that control neuroimmune activity through twoway communications. Anatomically, the vagus nerve penetrates the intestinal mucosa and contacts MCs, while vagotomy reduces MCs density (Stead et al., 2006). Activation of nAChRs can inhibit IgE-induced bone-marrow-derived MC degranulation in mice (Kageyama-Yahara et al., 2008). VNS can induce an increase in histamine-immune response in intestinal mucosal MCs, which may be mediated by a decrease in MC degranulation (Stead et al., 2006). Lipid-rich enteral nutrition weakened intestinal $\mathrm{MC}$ activation in the post-operative ileus (POI) model and the LPS-induced acute enteritis model via stimulating vagal pathway (Lubbers et al., 2009; de Haan et al., 2013).

Intestinal DCs participate in antigen presentation, regulate lymphocyte differentiation, and simultaneously express multiple neurotransmitter receptors, allowing regulation by nerves (Alpaerts et al., 2015). For example, $\beta-2$ adrenal receptor activation stimulates the anti-inflammatory properties of DCs in vitro, which are evidenced by enhancing endocytosis and increasing the production of IL-10 (Nijhuis et al., 2014). The DCs express M3, M4, and M5 receptors. Cholinergic agonist Carbachol induces DC differentiation, increasing expression of HLA-DR and CD86 and enhancing TNF- $\alpha$ and IL- 8 production, which are completely blocked by atropine (Salamone et al., 2011). Finally, ILCs are primarily associated with ENS. Neurotrophic factors or neuropeptide was demonstrated to have potentiality of immunoregulation for ILCs. EGCs secret various neurotrophic factors of the GDNF family, which induces the expression and secretion of IL-22 in ILC3 cells. This supports intestinal host defense and homeostasis via the production of mucin and antimicrobial peptides by epithelial cells. Neuroregulatory receptor RET, expressed in intestinal ILC3 cells, controls the activation of IL-22 and ERK-3, which is downstream factors of the p38MAPK/Akt signaling (Ibiza et al., 2016). ILC2 cell expresses multiple neuropeptide receptors including NMUR1. The expression of NMUR1 was increased under infection. Neuropeptide NMU plays an important role in the production of IL-25 and IL-33, and activation of ILC2-mediated immunity, such as responses to lung and intestinal helminth infections (Cardoso et al., 2017; Wallrapp et al., 2017). Collectively, ANS has a potential function to regulate the immune function of the intestinal cells.

\section{PARASYMPATHETIC NERVES SYSTEM AND INTESTINAL DISEASES}

Cholinergic anti-inflammatory pathway was first identified by Borovikova et al. (2000) Vagal nerve stimulation protects against lethal septic shock induced by LPS. Afferent vagal activity mediates a cytokine-induced pyretic response (Fleshner et al., 1998). The effects of CAIP on intestinal immune function may include: indirectly regulating intestinal inflammation via altering systemic inflammation through splenic nerve (Huston et al., 2006; Rosas-Ballina et al., 2008; Figure 2), or directly regulating intestinal inflammation through parasympathetic nerve (Matteoli et al., 2014). We will discuss the antiinflammatory effects of PNS in various diseases below.

\section{Inflammatory Bowel Disease (IBDs)}

Inflammatory bowel diseases (IBDs), including Crohn's disease and ulcerative colitis, are complex diseases at the clinical, immunological, genetic, molecular and microbial levels. Parasympathetic innervation is involved in the pathophysiology process of IBDs in animal models and patients. A clinical study found vagal nerve dysfunction in $45 \%$ of tested patients with ulcerative colitis (UC) (Lindgren et al., 1993). Ghia et al. (2006) showed that subdiaphragmatic vagotomy aggravated acute experimental colitis in mice treated with DSS for 5- or 3-day-intrarectal DNBS injection. Subdiaphragmatic vagotomy increased the likelihood and severity of acute episodes in chronic experimental colitis (Ghia et al., 2007). O’Mahony et al. (2009) showed that subdiaphragmatic vagotomy aggravated acute experimental colitis after 5 days of DSS administration. The severity of colitis caused by acute DSS in $\alpha 7-\mathrm{nAChR}^{-/-}$mice increased in the depression mouse model, and was relieved after treatment with choline chloride ( $\alpha 7$-nAChR-specific agonist) (Ghia et al., 2009). However, data have demonstrated that vagotomy has no significant effect on the course of colitis in mice treated with DSS for 7 days (Willemze et al., 2018). These differences can be explained by the discrepancy in duration of treatment, methods of experimental colitis induced, and the vagotomy. Opposite of vagotomy is VNS, which has been shown to activate the CAIP and alleviate inflammatory bowel disease. Chronic VNS activates the choline anti-inflammatory pathway, with MAPK/NF- $\kappa \mathrm{B}$ signaling pathway attenuating experimental colitis (Sun et al., 2013). A clinical study showed that long-term VNS improved vagal tone in 5 of the 7 patients with Crohn's disease (Bonaz et al., 2016). In addition to VNS, whole-body nicotine therapy can inhibit acute DSS-induced colitis by downregulating pro-inflammatory cytokine IL-6 and TNF- $\alpha$ (Ghia et al., 2006; Hayashi et al., 2014). Acetylcholinesterase inhibitors such as neostigmine, physostigmine, galantamine can attenuate intestinal damage in a model of DNBS-induced colitis in rats (Miceli and Jacobson, 2003; Ji et al., 2014). Lipid-rich enteral 
nutrition via activation of vagus nerve regulated mucosal MC activation to alleviate LPS-induced acute enteritis in mice (de Haan et al., 2013). A recent study found that ultrasound therapy can alleviate DSS-induced colitis through the $\alpha 7-n$ AChRsmediated CAIP (Nunes et al., 2019). These data suggest that vagal dysfunction plays an important role in the pathogenesis of IBDs. Inhibition of vagal activity by inhibitors, denervation, and gene editing may aggravate IBDs. Conversely, the CAIP can be activated by physical stimulation and receptor activators, alleviating colitis, in which $\alpha 7-\mathrm{nAChR}$ receptors may play an important role.

\section{Irri' Bowel Syndrome (IBS)}

Irri' bowel syndrome (IBS) is one of the most common disorders of gut-brain interaction. ANS may be an effective target for the treatment of IBS. The abnormality of the autonomic nerve is an objective physiological factor of IBS (Cheng et al., 2013). The results from clinical studies demonstrated the impaired parasympathetic activity and enhanced sympathetic tone in patients (Pellissier et al., 2010; Chalaye et al., 2012; Mazur et al., 2012; Tanaka et al., 2018). Mood regulation can alter autonomic dysfunction in IBDs patients, whereas autonomic dysfunction persists regardless of mood regulation in IBS patients (Pellissier et al., 2010). Antidepressants can improve the gastrointestinal and psychological status of patients with IBS and improve the stress response of ANS (Wan and Chen, 2010). VNS is considered a potential therapeutic approach for IBS. Transcutaneous electrical vagal nerve stimulation with deep slow breathing, combined with electrical and physiological modulation of vagal tone, enhanced gastroduodenal motility and reduced somatic pain sensitivity (Frokjaer et al., 2016).

\section{Post-operative lleus (POI)}

Post-operative ileus, characterized by gastrointestinal motor dysfunction accompanied by nausea, impaired oral feeding, vomiting, abdominal distension and delayed expulsion of stool or flatus, is a frequent complication of abdominal surgery (Vather et al., 2014). The pathogenesis of POI mainly includes inflammatory responses in the intestinal wall and autonomic nerve disorders represented by increased sympathetic activity and impaired parasympathetic activity (Bauer and Boeckxstaens, 2004). In a mouse model of POI, neuroanatomical evidence demonstrates the existence of the vagal anti-inflammatory reflex in the intestinal wall. Abdominal surgery resulted in subtle inflammation of intestine, where sensory and motor vagal neurons are activated during POI. The vagus nerve is mainly output to the inflammatory region, and $42 \%$ of motor neurons innervating the intestine expressed c-fos in contrast to $7 \%$ of splenic nerve (Cailotto et al., 2012). Nicotine produces an antiinflammatory effect on peritoneal macrophages by activating $\alpha 7$ nAChR. VNS improves inflammation and post-operative bowel obstruction in the POI model by activating STAT3 pathways in intestinal macrophages, both of which are anti-inflammatory by the $\alpha 7$-nAChR-mediated Jak2-Stat3 signaling pathway (de Jonge et al., 2005). VNS failed in the alpha-7nAChR ${ }^{-/-}$ mouse POI model (Matteoli et al., 2014), emphasizing the vagus nerve's anti-inflammatory effects mediated by $\alpha 7-\mathrm{nAChR}$.
Stimulation of nicotine cholinergic receptors in the POI model reduces the intestinal inflammatory response and counteracts the delayed gastric emptying (The et al., 2007). Administration of lipid-rich enteral nutrition relieves POI by activating vagus nerve, dampening pro-inflammatory cytokine secretion (Lubbers et al., 2009). 5-HT4R agonists mediate ACh release from intestinal neurons, which reduces inflammatory activity in macrophages in POI rats (Tsuchida et al., 2011), suggesting that not only vagus nerve produces an anti-inflammatory effect, ENS also mediates the CAIP. Activation of the vagus nerve alleviates inflammation and symptoms of post-operative intestinal obstruction. Therefore, regulation of ANS might be a new clinical strategy for the prevention of post-operative intestinal obstruction.

\section{SYMPATHETIC NERVES SYSTEM AND INTESTINAL DISEASES}

Sympathetic nervous system appears to play a more important role in intestinal inflammatory response compared with PNS. CAIP requires the involvement of the sympathetic nerves (RosasBallina et al., 2008). Depletion of noradrenaline by reserpine in rats prevented the anti-inflammatory action of vagal stimulation (Rosas-Ballina et al., 2008). Patients with UC showed hypertonic sympathetic in IBDs (Maule et al., 2007), while the loss of sympathetic fibers was discovered in CD patients (Straub et al., 2008). The changes in the SNS may be related to the occurrence and outcome of IBDs. Sympathectomy (6-OHDA) alleviated acute DSS colitis and aggravated chronic DSS colitis in wildtype mice and chronic colitis in $\mathrm{Il}-10^{-/-}$mice (Straub et al., 2008). Willemze et al. (2018) reported that sympathectomy rather than vagus nerve has a significant damaging effect on acute DSS-induced colitis in mice, while electrical stimulation of superior mesenteric nerve improves colitis. Distinctness in neurotransmitter concentrations due to different approaches to sympathectomy and the variable expression of adrenergic receptor subtypes in the intestinal inflammatory process explain the conflicting results. The study found that $\beta 2$ and $\beta 3$ adrenaline receptors could act as anti-inflammatory agents at high levels of norepinephrine (Borger et al., 1998; Vasina et al., 2008; Nijhuis et al., 2014), whereas $\alpha 2$ receptors had a relatively high norepinephrine affinity (Bai et al., 2009). Catecholamines have a significant effect on the composition of the microbial population in the lumen and its interaction with epithelial cells, which may affect the outcome of intestinal immunity (Lyte et al., 2011).

Sympathetic nerves may be involved in chemotherapyinduced intestinal mucositis. Chemotherapy drugs have been documented to damage the sympathetic nerve (Lucas et al., 2013). 5 -FU-induced damage to the intestinal sympathetic nerve was dose-dependent and resulted in a decrease of ISCs. 6-OHDA reduced the numbers of ISCs in the mouse jejunal crypt along with a reduction of numbers of Paneth cells. Isoproterenol (ISO), activating the beta-2 adrenergic receptor on the ISCs, ameliorated the damage to the intestine after chemotherapy, which is mediated by decreasing cellular apoptosis and protecting intestinal sympathetic nerve (Zeng et al., 2020). Thus, activation 


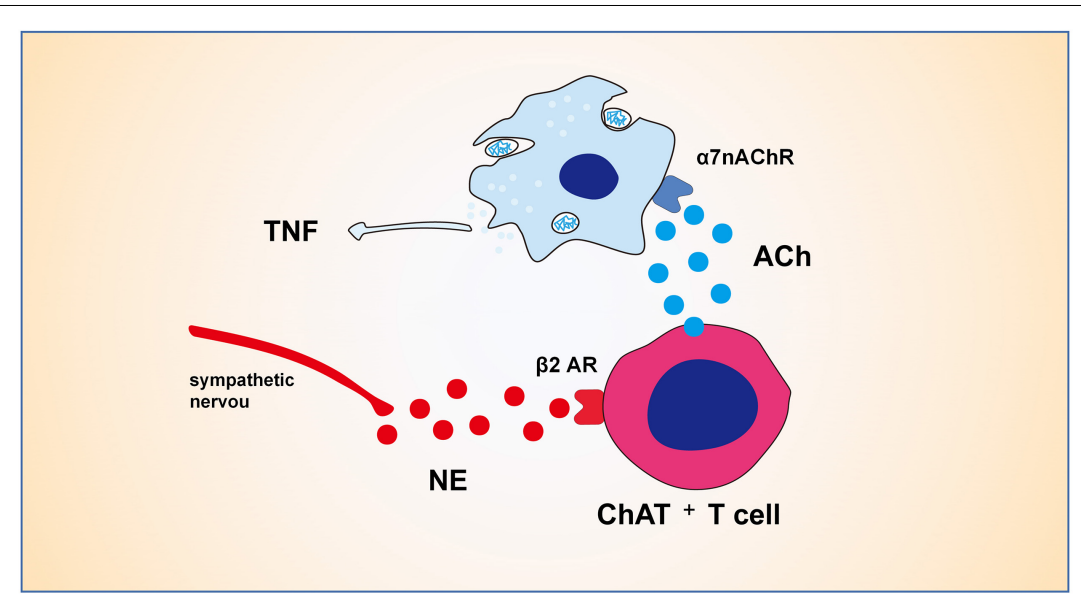

FIGURE 2 | Mechanisms of cholinergic anti-inflammatory pathway. The CAIP depends on norepinephrine produced by splenic sympathetic fibers, which can lead $\mathrm{ChAT}^{+} \mathrm{T}$ cell to release ACh through $\beta 2$ receptor. ACh from ChAT ${ }^{+} \mathrm{T}$ cell binds to the $\alpha 7-\mathrm{nAChR}$ on the bone marrow-derived non- $\mathrm{T}$ cells like macrophages along with inhibiting LPS-mediated cytokine production.

of sympathetic pathways or neuroprotective drugs may be a new therapeutic strategy to prevent the side effects of chemotherapy.

\section{CONCLUSION AND FUTURE APPLICATION OF AUTONOMIC NERVE REGULATION ON INTESTINE}

The regulation of intestinal homeostasis by ANS may be a valuable tool in the clinic and open a new treatment strategy for various refractory or chronic intestinal diseases. To investigate the effects of ANS on the intestine, we need to understand two major effects of ANS: (1) the regulation of IEC proliferation and (2) the immune system in intestine.

Autonomic nerve system regulates IEC proliferation and plays an effective role in intestinal mucosal regeneration after trauma, surgery and infection. ANS signaling induces stem cell proliferation and differentiation, which maintains different types of epithelial cells and affects intestinal absorption spectrum. Some cancers in the gastrointestinal tract, such as colon cancer, are thought to originate from stem cells, which maintain similar properties to ISCs under tumor conditions (Barker et al., 2009; Merlos-Suarez et al., 2011; Schepers et al., 2012; Cortina et al., 2017; Shimokawa et al., 2017). Several intestinal cancer cells express autonomic receptors, and neurotransmitters or receptor activators, which might affect tumor cell proliferation (Park and Cho, 2008; Huang et al., 2012; Coelho et al., 2015; Wang et al., 2016). ANS regulation might be used as a new target to develop an effective anti-cancer strategy. ANS can be protected and activated in the intestine through drugs, preventing the short- and long-term complications after chemotherapy. Because post-chemotherapy intestinal nerve injury may be involved in the formation of intestinal inflammation, isoproterenol has been shown to ameliorate post-chemotherapy intestinal injury (Zeng et al., 2020). Therefore, the ANS signaling can effectively reduce the intestinal damage after chemotherapy. These will increase the quality of life and survival rate of cancer patients. In conclusion, understanding the role and mechanism of ANS in regulating IECs might help to increase current therapeutic strategies and achieve breakthroughs in clinical practice.

Autonomic nerve system, as a bridge between CNS and gut, may be a better therapeutic target relative to unmanageable CNS or complex intestinal environment. Autonomic disorders, such as IBDs, IBS and POI, characterized by impaired parasympathetic activity and enhanced sympathetic tone in patients. The immune/inflammatory response of ANS to intestine has been used in clinical trials. Researchers have identified the role of CAIPs in POI and CD (Bonaz et al., 2016; Stakenborg et al., 2017). Stakenborg et al. (2017) present abdominal vagal nerve stimulation as a treatment for post-operative intestinal obstruction. Abdominal VNS attenuates LPS-induced IL-6 and IL-8 elevations in whole blood collected on day 1 after colectomy without significant side effects in colectomy patients. VNS is safe and effective for patients with post-operative intestinal obstruction and has certain anti-inflammatory effects. VNS normalizes vagal tone regardless of the initial state of activation, which is advantageous in patients with a low vagal tone.

Although there is increasing numbers of the studies about ANS regulation for intestine, the controversy exists in the complete neural circuit of ANS regulation. How do we coordinate many roles of ANS on the gut? Does CAIP work through the spleen nerve or via the vagal nerve extending into the intestinal wall? Where the SNS are located in the CAIP? Further mechanism of sympathetic and parasympathetic regulation of inflammation is needed, which will obtain efficient regulation methods, enabling ANS-mediated regulation of intestinal homeostasis.

\section{AUTHOR CONTRIBUTIONS}

HoD and LS designed the study. All authors drafted the manuscript, read and approved the manuscript. 


\section{FUNDING}

The study was supported in part by the National Natural Science Foundation of China (Grant Nos. 81960104 and 81860026), Key R\&D plan of Jiangxi Provincial Science and Technology Department (Grant Nos. 20192BBG70043 and 20202ACB206009), Interdisciplinary Innovation Fund of Natural Science, Nanchang University (Grant Nos. 9166-27060003-YB13 and 202010403062). Project of Traditional Chinese Medicine in Jiangxi

\section{REFERENCES}

Alpaerts, K., Buckinx, R., Adriaensen, D., van Nassauw, L., and Timmermans, J. P. (2015). Identification and putative roles of distinct subtypes of intestinal dendritic cells in neuroimmune communication: what can be learned from other organ systems? Anat. Rec. 298, 903-916. doi: 10.1002/ar.23106

Anini, Y., and Brubaker, P. (2003). Muscarinic receptors control glucagon-like peptide 1 secretion by human endocrine L cells. Endocrinology 144, 3244-3250. doi: 10.1210/en.2003-0143

Aponte, Y., Atasoy, D., and Sternson, S. (2011). AGRP neurons are sufficient to orchestrate feeding behavior rapidly and without training. Nat. Neurosci. 14, 351-355. doi: 10.1038/nn.2739

Bai, A., Lu, N., Guo, Y., Chen, J., and Liu, Z. (2009). Modulation of inflammatory response via alpha2-adrenoceptor blockade in acute murine colitis. Clin. Exp. Immunol. 156, 353-362. doi: 10.1111/j.1365-2249.2009.03894.x

Barker, N., Ridgway, R. A., van Es, J. H., van de Wetering, M., Begthel, H., van den Born, M., et al. (2009). Crypt stem cells as the cells-of-origin of intestinal cancer. Nature 457, 608-611.

Barker, N., van Es, J. H., Kuipers, J., Kujala, P., van den Born, M., Cozijnsen, M., et al. (2007). Identification of stem cells in small intestine and colon by marker gene Lgr5. Nature 449, 1003-1007. doi: 10.1038/nature06196

Bauer, A. J., and Boeckxstaens, G. E. (2004). Mechanisms of postoperative ileus. Neurogastroenterol. Motil. 16(Suppl. 2), 54-60. doi: 10.1111/j.1743-3150.2004. 00558.x

Bellinger, D., Lorton, D., Felten, S., and Felten, D. (1992). Innervation of lymphoid organs and implications in development, aging, and autoimmunity. Int. J. Immunopharmacol. 14, 329-344. doi: 10.1016/0192-0561(92)90162-e

Birchenough, G., Nyström, E., Johansson, M., and Hansson, G. (2016). A sentinel goblet cell guards the colonic crypt by triggering Nlrp6-dependent Muc2 secretion. Science 352, 1535-1542. doi: 10.1126/science.aaf7419

Bohorquez, D. V., Shahid, R. A., Erdmann, A., Kreger, A. M., Wang, Y., Calakos, N., et al. (2015). Neuroepithelial circuit formed by innervation of sensory enteroendocrine cells. J. Clin. Invest. 125, 782-786. doi: 10.1172/jci78361

Bonaz, B., Sinniger, V., Hoffmann, D., Clarencon, D., Mathieu, N., Dantzer, C., et al. (2016). Chronic vagus nerve stimulation in Crohn's disease: a 6-month follow-up pilot study. Neurogastroenterol. Motil. 28, 948-953. doi: 10.1111/ nmo. 12792

Borger, P., Hoekstra, Y., Esselink, M. T., Postma, D. S., Zaagsma, J., Vellenga, E., et al. (1998). Beta-adrenoceptor-mediated inhibition of IFN-gamma, IL-3, and GM-CSF mRNA accumulation in activated human T lymphocytes is solely mediated by the beta2-adrenoceptor subtype. Am. J. Respir. Cell Mol. Biol. 19, 400-407. doi: 10.1165/ajrcmb.19.3.2765

Borovikova, L. V., Ivanova, S., Zhang, M., Yang, H., Botchkina, G. I., Watkins, L. R., et al. (2000). Vagus nerve stimulation attenuates the systemic inflammatory response to endotoxin. Nature 405, 458-462. doi: 10.1038/35013070

Browning, K. N., and Travagli, R. A. (2014). Central nervous system control of gastrointestinal motility and secretion and modulation of gastrointestinal functions. Compr. Physiol. 4, 1339-1368. doi: 10.1002/cphy.c1 30055

Cailotto, C., Costes, L., van der Vliet, J., van Bree, S. H., van Heerikhuize, J. J., Buijs, R., et al. (2012). Neuroanatomical evidence demonstrating the existence of the vagal anti-inflammatory reflex in the intestine. Neurogastroenterol. Motil. 24, 191-200. doi: 10.1111/j.1365-2982.2011.01824.x

Cailotto, C., Gomez-Pinilla, P. J., Costes, L. M., van der Vliet, J., Di Giovangiulio, M., Nemethova, A., et al. (2014). Neuro-anatomical evidence indicating indirect
Province (Grant No. 2019A176). National undergraduate innovation and entrepreneurship training program (Grant No. 202010403062).

\section{ACKNOWLEDGMENTS}

Our thanks go to Qingxian Zhu (Nanchang University, China), who provided helpful suggestions on the section of autonomic nervous system and intestinal diseases.

modulation of macrophages by vagal efferents in the intestine but not in the spleen. PLoS One 9:e87785. doi: 10.1371/journal.pone.0087785

Callaghan, B. D. (1991). The effect of pinealectomy and autonomic denervation on crypt cell proliferation in the rat small intestine. J. Pineal Res. 10, 180-185. doi: 10.1111/j.1600-079x.1991.tb00813.x

Cameron, H. L., and Perdue, M. H. (2007). Muscarinic acetylcholine receptor activation increases transcellular transport of macromolecules across mouse and human intestinal epithelium in vitro. Neurogastroenterol. Motil. 19, 47-56. doi: 10.1111/j.1365-2982.2006.00845.x

Cardoso, V., Chesne, J., Ribeiro, H., Garcia-Cassani, B., Carvalho, T., Bouchery, T., et al. (2017). Neuronal regulation of type 2 innate lymphoid cells via neuromedin U. Nature 549, 277-281. doi: 10.1038/nature23469

Chalaye, P., Goffaux, P., Bourgault, P., Lafrenaye, S., Devroede, G., Watier, A., et al. (2012). Comparing pain modulation and autonomic responses in fibromyalgia and irritable bowel syndrome patients. Clin. J. Pain 28, 519-526. doi: 10.1097/ ajp.0b013e31823ae69e

Cheng, P., Shih, W., Alberto, M., Presson, A. P., Licudine, A., Mayer, E. A., et al. (2013). Autonomic response to a visceral stressor is dysregulated in irritable bowel syndrome and correlates with duration of disease. Neurogastroenterol. Motil. 25, e650-e659.

Coelho, M., Moz, M., Correia, G., Teixeira, A., Medeiros, R., and Ribeiro, L. (2015). Antiproliferative effects of beta-blockers on human colorectal cancer cells. Oncol. Rep. 33, 2513-2520. doi: 10.3892/or.2015.3874

Cortina, C., Turon, G., Stork, D., Hernando-Momblona, X., Sevillano, M., Aguilera, M., et al. (2017). A genome editing approach to study cancer stem cells in human tumors. EMBO Mol. Med. 9, 869-879. doi: 10.15252/emmm.201707550

Costa, M., Brookes, S. J., and Hennig, G. W. (2000). Anatomy and physiology of the enteric nervous system. Gut 47(Suppl. 4), v15-v26.

Costantini, T. W., Bansal, V., Krzyzaniak, M., Putnam, J. G., Peterson, C. Y., Loomis, W. H., et al. (2010). Vagal nerve stimulation protects against burninduced intestinal injury through activation of enteric glia cells. Am. J. Physiol. Gastrointest. Liver Physiol. 299, G1308-G1318.

Costantini, T. W., Krzyzaniak, M., Cheadle, G. A., Putnam, J. G., Hageny, A. M., Lopez, N., et al. (2012). Targeting alpha-7 nicotinic acetylcholine receptor in the enteric nervous system: a cholinergic agonist prevents gut barrier failure after severe burn injury. Am. J. Pathol. 181, 478-486.

Dailey, M. J. (2014). Nutrient-induced intestinal adaption and its effect in obesity. Physiol. Behav. 136, 74-78. doi: 10.1016/j.physbeh.2014.03.026

Davis, E. A., Washington, M. C., Yaniz, E. R., Phillips, H., Sayegh, A. I., and Dailey, M. J. (2017). Long-term effect of parasympathetic or sympathetic denervation on intestinal epithelial cell proliferation and apoptosis. Exp. Biol. Med. 242, 1499-1507. doi: 10.1177/1535370217724790

Davis, E. A., Zhou, W., and Dailey, M. J. (2018). Evidence for a direct effect of the autonomic nervous system on intestinal epithelial stem cell proliferation. Physiol. Rep. 6:e13745.

de Haan, J. J., Hadfoune, M., Lubbers, T., Hodin, C., Lenaerts, K., Ito, A., et al. (2013). Lipid-rich enteral nutrition regulates mucosal mast cell activation via the vagal anti-inflammatory reflex. Am. J. Physiol. Gastrointest. Liver Physiol. 305, G383-G391.

de Jonge, W. J., van der Zanden, E. P., The, F. O., Bijlsma, M. F., van Westerloo, D. J., Bennink, R. J., et al. (2005). Stimulation of the vagus nerve attenuates macrophage activation by activating the Jak2-STAT3 signaling pathway. Nat. Immunol. 6, 844-851. doi: 10.1038/ni1229

Delgado, M., Munoz-Elias, E. J., Gomariz, R. P., and Ganea, D. (1999). Vasoactive intestinal peptide and pituitary adenylate cyclase-activating polypeptide 
prevent inducible nitric oxide synthase transcription in macrophages by inhibiting NF-kappa B and IFN regulatory factor 1 activation. J. Immunol. 162, 4685-4696.

Di Giovangiulio, M., Bosmans, G., Meroni, E., Stakenborg, N., Florens, M., Farro, G., et al. (2016). Vagotomy affects the development of oral tolerance and increases susceptibility to develop colitis independently of the alpha-7 nicotinic receptor. Mol. Med. 22, 464-476. doi: 10.2119/molmed.2016.00062

Elenkov, I. J., Wilder, R. L., Chrousos, G. P., and Vizi, E. S. (2000). The sympathetic nerve-an integrative interface between two supersystems: the brain and the immune system. Pharmacol. Rev. 52, 595-638.

Erlinge, D., Brunkwall, J., and Edvinsson, L. (1994). Neuropeptide Y stimulates proliferation of human vascular smooth muscle cells: cooperation with noradrenaline and Atp. Regul. Pept. 50, 259-265. doi: 10.1016/0167-0115(94) 90006-X

Erlinge, D., Yoo, H., Edvinsson, L., Reis, D. J., and Wahlestedt, C. (1993). Mitogenic effects of Atp on vascular smooth muscle cells VS. other growth factors and sympathetic cotransmitters. Am. J. Physiol. 265, H1089-H1097.

Felten, D., Felten, S., Carlson, S., Olschowka, J., and Livnat, S. (1985). Noradrenergic and peptidergic innervation of lymphoid tissue. J. Immunol. 135, 755s-765s.

Fleshner, M., Goehler, L. E., Schwartz, B. A., Mcgorry, M., Martin, D., Maier, S. F., et al. (1998). Thermogenic and corticosterone responses to intravenous cytokines (IL-1beta and TNF-alpha) are attenuated by subdiaphragmatic vagotomy. J. Neuroimmunol. 86, 134-141. doi: 10.1016/s0165-5728(98)00 026-5

Frokjaer, J. B., Bergmann, S., Brock, C., Madzak, A., Farmer, A. D., Ellrich, J., et al. (2016). Modulation of vagal tone enhances gastroduodenal motility and reduces somatic pain sensitivity. Neurogastroenterol. Motil. 28, 592-598. doi: $10.1111 /$ nmo. 12760

Gabanyi, I., Muller, P. A., Feighery, L., Oliveira, T. Y., Costa-Pinto, F. A., and Mucida, D. (2016). Neuro-immune interactions drive tissue programming in intestinal macrophages. Cell 164, 378-391. doi: 10.1016/j.cell.2015.12.023

Gabella, G., and Costa, M. (1968). Adrenergic fibres in the mucous membrane of guinea pig alimentary tract. Experientia 24, 706-707. doi: 10.1007/bf02138328

Gareau, M. G., Jury, J., and Perdue, M. H. (2007). Neonatal maternal separation of rat pups results in abnormal cholinergic regulation of epithelial permeability. Am. J. Physiol. Gastrointest. Liver Physiol. 293, G198-G203.

Ghia, J. E., Blennerhassett, P., Deng, Y., Verdu, E. F., Khan, W. I., and Collins, S. M. (2009). Reactivation of inflammatory bowel disease in a mouse model of depression. Gastroenterology 136, 2280-2288. doi: 10.1053/j.gastro.2009.02.069

Ghia, J. E., Blennerhassett, P., El-Sharkawy, R. T., and Collins, S. M. (2007). The protective effect of the vagus nerve in a murine model of chronic relapsing colitis. Am. J. Physiol. Gastrointest. Liver Physiol. 293, G711-G718.

Ghia, J. E., Blennerhassett, P., Kumar-Ondiveeran, H., Verdu, E. F., and Collins, S. M. (2006). The vagus nerve: a tonic inhibitory influence associated with inflammatory bowel disease in a murine model. Gastroenterology 131, 11221130. doi: $10.1053 /$ j.gastro.2006.08.016

Goldstein, N., McKnight, A. D., Carty, J. R. E., Arnold, M., Betley, J. N., and Alhadeff, A. L. (2021). Hypothalamic detection of macronutrients via multiple gut-brain pathways. Cell Metab. 33, 676-687. doi: 10.1016/j.cmet.2020.12.018

Greicius, G., Kabiri, Z., Sigmundsson, K., Liang, C., Bunte, R., Singh, M. K., et al. (2018). a pericryptal stromal cells are the critical source of Wnts and RSPO3 for murine intestinal stem cells in vivo. Proc. Natl. Acad. Sci. U.S.A. 115, E3173-E3181.

Greig, C. J., and Cowles, R. A. (2017). Muscarinic acetylcholine receptors participate in small intestinal mucosal homeostasis. J. Pediatr. Surg. 52, 10311034. doi: 10.1016/j.jpedsurg.2017.03.037

Guereschi, M. G., Araujo, L. P., Maricato, J. T., Takenaka, M. C., Nascimento, V. M., Vivanco, B. C., et al. (2013). Beta2-adrenergic receptor signaling in $\mathrm{CD} 4+$ Foxp3+ regulatory $\mathrm{T}$ cells enhances their suppressive function in a PKA-dependent manner. Eur. J. Immunol. 43, 1001-1012. doi: 10.1002/eji. 201243005

Gulbransen, B., and Sharkey, K. (2009). Purinergic neuron-to-glia signaling in the enteric nervous system. Gastroenterology 136, 1349-1358. doi: 10.1053/j.gastro. 2008.12.058

Gulbransen, B. D., Bains, J. S., and Sharkey, K. A. (2010). Enteric glia are targets of the sympathetic innervation of the myenteric plexus in the guinea pig distal colon. J. Neurosci. 30, 6801-6809. doi: 10.1523/jneurosci.0603-10.2010
Gustafsson, J., Ermund, A., Johansson, M., Schütte, A., Hansson, G., and Sjövall, H. (2012). An ex vivo method for studying mucus formation, properties, and thickness in human colonic biopsies and mouse small and large intestinal explants. Am. J. Physiol. Gastrointest. Liver Physiol. 302, G430-G438.

Hayashi, S., Hamada, T., Zaidi, S. F., Oshiro, M., Lee, J., Yamamoto, T., et al. (2014). Nicotine suppresses acute colitis and colonic tumorigenesis associated with chronic colitis in mice. Am. J. Physiol. Gastrointest. Liver Physiol. 307, G968-G978.

Huang, X. Y., Wang, H. C., Yuan, Z., Huang, J., and Zheng, Q. (2012). Norepinephrine stimulates pancreatic cancer cell proliferation, migration and invasion via beta-adrenergic receptor-dependent activation of P38/MAPK pathway. Hepatogastroenterology 59, 889-893.

Huston, J. M., Ochani, M., Rosas-Ballina, M., Liao, H., Ochani, K., Pavlov, V. A., et al. (2006). Splenectomy inactivates the cholinergic antiinflammatory pathway during lethal endotoxemia and polymicrobial sepsis. J. Exp. Med. 203, 16231628. doi: 10.1084/jem.20052362

Ibiza, S., Garcia-Cassani, B., Ribeiro, H., Carvalho, T., Almeida, L., Marques, R., et al. (2016). Glial-cell-derived neuroregulators control type 3 innate lymphoid cells and gut defence. Nature 535, 440-443. doi: 10.1038/nature18644

Iwasaki, M., Akiba, Y., and Kaunitz, J. D. (2019). Recent advances in vasoactive intestinal peptide physiology and pathophysiology: focus on the gastrointestinal system. F1000Research 8:F1000 Faculty Rev-1629.

Ji, H., Rabbi, M. F., Labis, B., Pavlov, V. A., Tracey, K. J., and Ghia, J. E. (2014). Central cholinergic activation of a vagus nerve-to-spleen circuit alleviates experimental colitis. Mucosal Immunol. 7, 335-347. doi: 10.1038/mi.2013.52

Kageyama-Yahara, N., Suehiro, Y., Yamamoto, T., and Kadowaki, M. (2008). IgEinduced degranulation of mucosal mast cells is negatively regulated via nicotinic acetylcholine receptors. Biochem. Biophys. Res. Commun. 377, 321-325. doi: 10.1016/j.bbrc.2008.10.004

Kennedy, M. F., Tutton, P. J., and Barkla, D. H. (1983). Adrenergic factors involved in the control of crypt cell proliferation in jejunum and descending colon of mouse. Clin. Exp. Pharmacol. Physiol. 10, 577-586. doi: 10.1111/j.1440-1681. 1983.tb00226.x

Khan, R. I., Yazawa, T., Anisuzzaman, A. S., Semba, S., Ma, Y., Uwada, J., et al. (2014). Activation of focal adhesion kinase via M1 muscarinic acetylcholine receptor is required in restitution of intestinal barrier function after epithelial injury. Biochim. Biophys. Acta 1842, 635-645. doi: 10.1016/j.bbadis.2013.12.007

Khedr, M., Abdelmotelb, A. M., Bedwell, T. A., Shtaya, A., Alzoubi, M. N., Abu, H. M., et al. (2018). Vasoactive intestinal peptide induces proliferation of human hepatocytes. Cell Prolif. 51:e12482. doi: 10.1111/cpr.12482

Lachat, J. J., and Goncalves, R. P. (1978). Influence of autonomic denervation upon the kinetics of the ileal epithelium of the rat. Cell Tissue Res. 192, 285-297.

Lavin, Y., Winter, D., Blecher-Gonen, R., David, E., Keren-Shaul, H., Merad, M., et al. (2014). Tissue-resident macrophage enhancer landscapes are shaped by the local microenvironment. Cell 159, 1312-1326. doi: 10.1016/j.cell.2014.11.018

Lin, R., Ding, Z., Ma, H., Shi, H., Gao, Y., Qian, W., et al. (2015). In vitro conditioned bone marrow-derived mesenchymal stem cells promote de novo functional enteric nerve regeneration, but not through directtransdifferentiation. Stem Cells 33, 3545-3557. doi: 10.1002/stem.2197

Lindgren, S., Stewenius, J., Sjolund, K., Lilja, B., and Sundkvist, G. (1993). Autonomic vagal nerve dysfunction in patients with ulcerative colitis. Scand. J. Gastroenterol. 28, 638-642. doi: 10.3109/00365529309096103

Lubbers, T., Luyer, M. D., de Haan, J. J., Hadfoune, M., Buurman, W. A., and Greve, J. W. (2009). Lipid-rich enteral nutrition reduces postoperative ileus in rats via activation of cholecystokinin-receptors. Ann. Surg. 249, 481-487. doi: 10.1097/sla.0b013e318194d187

Lucas, D., Scheiermann, C., Chow, A., Kunisaki, Y., Bruns, I., Barrick, C., et al. (2013). Chemotherapy-induced bone marrow nerve injury impairs hematopoietic regeneration. Nat. Med. 19, 695-703. doi: 10.1038/nm.3155

Lundgren, O., Jodal, M., Jansson, M., Ryberg, A. T., and Svensson, L. (2011). Intestinal epithelial stem/progenitor cells are controlled by mucosal afferent nerves. PLoS One 6:e16295. doi: 10.1371/journal.pone.0016295

Lyte, M., Vulchanova, L., and Brown, D. R. (2011). Stress at the intestinal surface: catecholamines and mucosa-bacteria interactions. Cell Tissue Res. 343, 23-32. doi: 10.1007/s00441-010-1050-0

Maceachern, S. J., Patel, B. A., Mckay, D. M., and Sharkey, K. A. (2011). Nitric oxide regulation of colonic epithelial ion transport: a novel role for enteric glia in the myenteric plexus. J. Physiol. 589, 3333-3348. doi: 10.1113/jphysiol.2011.207902 
Magnotti, L. J., and Deitch, E. A. (2005). Burns, bacterial translocation, gut barrier function, and failure. J. Burn Care Rehabil. 26, 383-391. doi: 10.1097/01.bcr. 0000176878.79267.e8

Matteoli, G., Gomez-Pinilla, P. J., Nemethova, A., Di Giovangiulio, M., Cailotto, C., van Bree, S. H., et al. (2014). A distinct vagal anti-inflammatory pathway modulates intestinal muscularis resident macrophages independent of the spleen. Gut 63, 938-948. doi: 10.1136/gutjnl-2013-304676

Maule, S., Pierangeli, G., Cevoli, S., Grimaldi, D., Gionchetti, P., Barbara, G., et al. (2007). Sympathetic hyperactivity in patients with ulcerative colitis. Clin. Auton Res. 17, 217-220. doi: 10.1007/s10286-007-0425-0

Mazur, M., Furgala, A., Jablonski, K., Mach, T., and Thor, P. (2012). Autonomic nervous system activity in constipation-predominant irritable bowel syndrome patients. Med. Sci. Monit. 18, R493-R499.

Mcconalogue, K., and Furness, J. B. (1994). Gastrointestinal neurotransmitters. Baillieres Clin. Endocrinol. Metab. 8, 51-76. doi: 10.1016/s0950-351x(05) 80226-5

Mcdole, J., Wheeler, L., Mcdonald, K., Wang, B., Konjufca, V., Knoop, K., et al. (2012). Goblet cells deliver luminal antigen to CD103+ dendritic cells in the small intestine. Nature 483, 345-349. doi: 10.1038/nature10863

Méndez-Ferrer, S., Battista, M., and Frenette, P. S. (2010). Cooperation of beta(2)and beta(3)-adrenergic receptors in hematopoietic progenitor cell mobilization. Ann. N.Y. Acad. Sci. 1192, 139-144.

Merlos-Suarez, A., Barriga, F. M., Jung, P., Iglesias, M., Cespedes, M. V., Rossell, D., et al. (2011). The intestinal stem cell signature identifies colorectal cancer stem cells and predicts disease relapse. Cell Stem Cell 8, 511-524. doi: 10.1016/ j.stem.2011.02.020

Miceli, P. C., and Jacobson, K. (2003). Cholinergic pathways modulate experimental dinitrobenzene sulfonic acid colitis in rats. Auton. Neurosci. 105, 16-24. doi: 10.1016/s1566-0702(03)00023-7

Morishita, K., Coimbra, R., Langness, S., Eliceiri, B. P., and Costantini, T. W. (2015). Neuroenteric axis modulates the balance of regulatory $\mathrm{T}$ cells and T-helper 17 cells in the mesenteric lymph node following trauma/hemorrhagic shock. Am. J. Physiol. Gastrointest. Liver Physiol. 309, G202-G208.

Musso, F., Lachat, J. J., Cruz, A. R., and Goncalves, R. P. (1975). Effect of denervation on the mitotic index of the intestinal epithelium of the rat. Cell Tissue Res. 163, 395-402.

Nance, D., and Burns, J. (1989). Innervation of the spleen in the rat: evidence for absence of afferent innervation. Brain Behav. Immun. 3, 281-290. doi: 10.1016/0889-1591(89)90028-7

Nasser, Y., Ho, W., and Sharkey, K. A. (2006). Distribution of adrenergic receptors in the enteric nervous system of the guinea pig, mouse, and rat. J. Comp. Neurol. 495, 529-553. doi: 10.1002/cne.20898

Nijhuis, L. E., Olivier, B. J., Dhawan, S., Hilbers, F. W., Boon, L., Wolkers, M. C., et al. (2014). Adrenergic beta2 receptor activation stimulates anti-inflammatory properties of dendritic cells in vitro. PLoS One 9:e85086. doi: 10.1371/journal. pone. 0085086

Norberg, K. A. (1964). Adrenergic innervation of the intestinal wall studied by fluorescence microscopy. Int. J. Neuropharmacol. 3, 379-382. doi: 10.1016/ 0028-3908(64)90067-x

Nunes, N. S., Chandran, P., Sundby, M., Visioli, F., Da, C. G. F., Burks, S. R., et al. (2019). Therapeutic ultrasound attenuates DSS-induced colitis through the cholinergic anti-inflammatory pathway. Ebiomedicine 45, 495-510. doi: 10.1016/j.ebiom.2019.06.033

Obara, K., Arai, K., Miyajima, N., Hatano, A., Tomita, Y., and Takahashi, K. (2000). Expression of $\mathrm{m} 2$ muscarinic acetylcholine receptor mRNA in primary culture of human prostate stromal cells. Urol. Res. 28, 196-200. doi: 10.1007/ s002400000113

Oben, J. A., Yang, S., Lin, H., Ono, M., and Diehl, A. M. (2003). Norepinephrine and neuropeptide Y promote proliferation and collagen gene expression of hepatic myofibroblastic stellate cells. Biochem. Biophys. Res. Commun. 302, 685-690. doi: 10.1016/s0006-291x(03)00232-8

Ochoa-Cortes, F., Turco, F., Linan-Rico, A., Soghomonyan, S., Whitaker, E., Wehner, S., et al. (2016). Enteric glial cells: a new frontier in neurogastroenterology and clinical target for inflammatory bowel diseases. Inflamm. Bowel Dis. 22, 433-449. doi: 10.1097/mib.0000000000000667

Okabe, Y., and Medzhitov, R. (2014). Tissue-specific signals control reversible program of localization and functional polarization of macrophages. Cell 157, 832-844. doi: 10.1016/j.cell.2014.04.016
Olivier, B. J., Cailotto, C., van der Vliet, J., Knippenberg, M., Greuter, M. J., Hilbers, F. W., et al. (2016). Vagal innervation is required for the formation of tertiary lymphoid tissue in colitis. Eur. J. Immunol. 46, 2467-2480. doi: 10.1002/eji. 201646370

Olofsson, P., Katz, D., Rosas-Ballina, M., Levine, Y., Ochani, M., Valdés-Ferrer, S., et al. (2012). $\alpha 7$ nicotinic acetylcholine receptor ( $\alpha 7 \mathrm{nAChR}$ ) expression in bone marrow-derived non-T cells is required for the inflammatory reflex. Mol. Med. 18, 539-543. doi: 10.2119/molmed.2011.00405

O'Mahony, C., van der Kleij, H., Bienenstock, J., Shanahan, F., and O'mahony, L. (2009). Loss of vagal anti-inflammatory effect: in vivo visualization and adoptive transfer. Am. J. Physiol. Regul. Integr. Comp. Physiol. 297, R1118-R1126.

Paris, H., Voisin, T., Remaury, A., Rouyer-Fessard, C., Daviaud, D., Langin, D., et al. (1990). Alpha-2 adrenoceptor in rat jejunum epithelial cells: characterization with $[3 \mathrm{H}] \mathrm{RX} 821002$ and distribution along the villus-crypt axis. J. Pharmacol. Exp. Ther. 254, 888-893.

Park, Y. S., and Cho, N. J. (2008). Enhanced proliferation of SNU-407 human colon cancer cells by muscarinic acetylcholine receptors. BMB Rep. 41, 803-807. doi: 10.5483/bmbrep.2008.41.11.803

Pellissier, S., Dantzer, C., Canini, F., Mathieu, N., and Bonaz, B. (2010). Psychological adjustment and autonomic disturbances in inflammatory bowel diseases and irritable bowel syndrome. Psychoneuroendocrino 35, 653-662. doi: 10.1016/j.psyneuen.2009.10.004

Pereira, A., McLaren, A., Bell, W. R., Copolov, D., and Dean, B. (2003). Potential clozapine target sites on peripheral hematopoietic cells and stromal cells of the bone marrow. Pharmacogenom. J. 3, 227-234. doi: 10.1038/sj.tpj.6500179

Phillips, R. J., and Powley, T. L. (2012). Macrophages associated with the intrinsic and extrinsic autonomic innervation of the rat gastrointestinal tract. Auton. Neurosci. 169, 12-27. doi: 10.1016/j.autneu.2012.02.004

Rosas-Ballina, M., Ochani, M., Parrish, W., Ochani, K., Harris, Y., Huston, J. et al. (2008). Splenic nerve is required for cholinergic antiinflammatory pathway control of Tnf in endotoxemia. Proc. Natl. Acad. Sci. U.S.A. 105, 11008-11013. doi: 10.1073/pnas.0803237105

Rosas-Ballina, M., Olofsson, P., Ochani, M., Valdés-Ferrer, S., Levine, Y., Reardon, C., et al. (2011). Acetylcholine-synthesizing T cells relay neural signals in a vagus nerve circuit. Science 334, 98-101. doi: 10.1126/science.1209985

Salamone, G., Lombardi, G., Gori, S., Nahmod, K., Jancic, C., Amaral, M., et al. (2011). Cholinergic modulation of dendritic cell function. J. Neuroimmunol. 236, 47-56. doi: 10.1016/j.jneuroim.2011.05.007

Sanders, V. M., Baker, R. A., Ramer-Quinn, D. S., Kasprowicz, D. J., Fuchs, B. A., and Street, N. E. (1997). Differential expression of the beta2-adrenergic receptor by Th1 and Th 2 clones: implications for cytokine production and B cell help. J. Immunol. 158, 4200-4210.

Satoh, Y. (1988). Atropine inhibits the degranulation of Paneth cells in ex-germfree mice. Cell Tissue Res. 253, 397-402.

Satoh, Y., Ishikawa, K., Oomori, Y., Takeda, S., and Ono, K. (1992). Bethanechol and a G-protein activator, $\mathrm{NaF} / \mathrm{AlCl} 3$, induce secretory response in Paneth cells of mouse intestine. Cell Tissue Res. 269, 213-220. doi: 10.1007/bf003 19611

Schaak, S., Cussac, D., Cayla, C., Devedjian, J. C., Guyot, R., Paris, H., et al. (2000) Alpha(2) adrenoceptors regulate proliferation of human intestinal epithelial cells. Gut 47, 242-250. doi: 10.1136/gut.47.2.242

Schaper, J., Wagner, A., Enigk, F., Brell, B., Mousa, S. A., Habazettl, H., et al. (2013). Regional sympathetic blockade attenuates activation of intestinal macrophages and reduces gut barrier failure. Anesthesiology 118, 134-142. doi: 10.1097/aln. 0b013e3182784c93

Schepers, A. G., Snippert, H. J., Stange, D. E., van den Born, M., van Es, J. H., van de Wetering, M., et al. (2012). Lineage tracing reveals Lgr5+ stem cell activity in mouse intestinal adenomas. Science 337, 730-735. doi: 10.1126/science. 1224676

Schutz, B., Jurastow, I., Bader, S., Ringer, C., von Engelhardt, J., Chubanov, V., et al. (2015). Chemical coding and chemosensory properties of cholinergic brush cells in the mouse gastrointestinal and biliary tract. Front. Physiol. 6:87. doi: 10.3389/fphys.2015.00087

Shimokawa, M., Ohta, Y., Nishikori, S., Matano, M., Takano, A., Fujii, M., et al. (2017). Visualization and targeting of LGR5(+) human colon cancer stem cells. Nature 545, 187-192. doi: 10.1038/nature22081

Shwartz, Y., Gonzalez-Celeiro, M., Chen, C.-L., Pasolli, H. A., Sheu, S.-H., Fan, S. M.-Y., et al. (2020). Cell types promoting goosebumps form a niche to 
regulate hair follicle stem cells. Cell 182, 578-593. doi: 10.1016/j.cell.2020. 06.031

Skok, M., Grailhe, R., and Changeux, J. P. (2005). Nicotinic receptors regulate B lymphocyte activation and immune response. Eur. J. Pharmacol. 517, 246-251. doi: 10.1016/j.ejphar.2005.05.011

Slater, T. W., Finkielsztein, A., Mascarenhas, L. A., Mehl, L. C., ButinIsraeli, V., and Sumagin, R. (2017). Neutrophil microparticles deliver active myeloperoxidase to injured mucosa to inhibit epithelial wound healing. J. Immunol. 198, 2886-2897. doi: 10.4049/jimmunol.1601810

Stakenborg, N., Wolthuis, A. M., Gomez-Pinilla, P. J., Farro, G., Di Giovangiulio, M., Bosmans, G., et al. (2017). Abdominal vagus nerve stimulation as a new therapeutic approach to prevent postoperative ileus. Neurogastroenterol. Motil. 29:13075.

Stead, R. H., Colley, E. C., Wang, B., Partosoedarso, E., Lin, J., Stanisz, A., et al. (2006). Vagal influences over mast cells. Auton. Neurosci. 125, 53-61. doi: 10.1016/j.autneu.2006.01.002

Straub, R. H., Grum, F., Strauch, U., Capellino, S., Bataille, F., Bleich, A., et al. (2008). Anti-inflammatory role of sympathetic nerves in chronic intestinal inflammation. Gut 57, 911-921. doi: 10.1136/gut.2007.125401

Sun, P., Zhou, K., Wang, S., Li, P., Chen, S., Lin, G., et al. (2013). Involvement of Mapk/Nf-kappaB signaling in the activation of the cholinergic antiinflammatory pathway in experimental colitis by chronic vagus nerve stimulation. PLoS One 8:e69424. doi: 10.1371/journal.pone.0069424

Takahashi, T., Ohnishi, H., Sugiura, Y., Honda, K., Suematsu, M., Kawasaki, T., et al. (2014). Non-neuronal acetylcholine as an endogenous regulator of proliferation and differentiation of Lgr5-positive stem cells in mice. FEBS J. 281, 4672-4690. doi: 10.1111/febs. 12974

Tanaka, Y., Kanazawa, M., Palsson, O. S., Tilburg, M., Gangarosa, L. M., Fukudo, S., et al. (2018). Increased postprandial colonic motility and autonomic nervous system activity in patients with irritable bowel syndrome: a prospective Study. J. Neurogastroenterol. Motil. 24, 87-95. doi: 10.5056/jnm16216

Teratani, T., Mikami, Y., Nakamoto, N., Suzuki, T., Harada, Y., Okabayashi, K., et al. (2020). The liver-brain-gut neural arc maintains the $\mathrm{T}$ cell niche in the gut. Nature 585, 591-596. doi: 10.1038/s41586-020-2 425-3

The, F. O., Boeckxstaens, G. E., Snoek, S. A., Cash, J. L., Bennink, R., Larosa, G. J., et al. (2007). Activation of the cholinergic anti-inflammatory pathway ameliorates postoperative ileus in mice. Gastroenterology 133, 1219-1228. doi: 10.1053/j.gastro.2007.07.022

Tsibulevskii, A., and Orlova, E. N. (1976). [Physiologic regeneration of jejunal epithelium following bilateral subdiaphragmatic vagotomy in rats]. Biull. Eksp. Biol. Med. 81, 236-237.

Tsuchida, Y., Hatao, F., Fujisawa, M., Murata, T., Kaminishi, M., Seto, Y., et al. (2011). Neuronal stimulation with 5-hydroxytryptamine 4 receptor induces anti-inflammatory actions via alpha7nACh receptors on muscularis macrophages associated with postoperative ileus. Gut 60, 638-647. doi: 10 . 1136/gut.2010.227546

Tutton, P. J. (1975). The influence of cholinoceptor activity on the mitotic rate in the crypts of Lieberkuhn in rat jejunum. Clin. Exp. Pharmacol. Physiol. 2, 269-276. doi: 10.1111/j.1440-1681.1975.tb03032.x

Tutton, P. J., and Barkla, D. H. (1977). The influence of adrenoceptor activity on cell proliferation in colonic crypt ipithelium and in colonic adenocarcinomata. Virchows Arch. B Cell. Pathol. 24, 139-146.

Tutton, P. J., and Helme, R. D. (1974). The influence of adrenoreceptor activity on crypt cell proliferation in the rat jejunum. Cell Tissue Kinet. 7, 125-136. doi: 10.1111/j.1365-2184.1974.tb00405.x

Uwada, J., Yazawa, T., Islam, M. T., Khan, M., Krug, S. M., Fromm, M., et al. (2017). Activation of muscarinic receptors prevents TNF-alpha-mediated intestinal epithelial barrier disruption through p38 MAPK. Cell Signal. 35, 188-196. doi: 10.1016/j.cellsig.2017.04.007
Valet, P., Senard, J. M., Devedjian, J. C., Planat, V., Salomon, R., Voisin, T., et al. (1993). Characterization and distribution of alpha 2-adrenergic receptors in the human intestinal mucosa. J. Clin. Invest. 91, 2049-2057. doi: 10.1172/jci116427 van der Zanden, E. P., Snoek, S., Heinsbroek, S., Stanisor, O., Verseijden, C., Boeckxstaens, G., et al. (2009). Vagus nerve activity augments intestinal macrophage phagocytosis via nicotinic acetylcholine receptor alpha4beta2. Gastroenterology 137, 1029-1039. doi: 10.1053/j.gastro.2009.04.057

Vasina, V., Abu-Gharbieh, E., Barbara, G., de Giorgio, R., Colucci, R., Blandizzi, C., et al. (2008). The beta3-adrenoceptor agonist SR58611A ameliorates experimental colitis in rats. Neurogastroenterol. Motil. 20, 1030-1041. doi: 10.1111/j.1365-2982.2008.01138.x

Vather, R., O'Grady, G., Bissett, I. P., and Dinning, P. G. (2014). Postoperative ileus: mechanisms and future directions for research. Clin. Exp. Pharmacol. Physiol. 41, 358-370. doi: 10.1111/1440-1681.12220

Vida, G., Peña, G., Kanashiro, A., Thompson-Bonilla Mdel, R., Palange, D., Deitch, E., et al. (2011). $\beta 2$-Adrenoreceptors of regulatory lymphocytes are essential for vagal neuromodulation of the innate immune system. FASEB J. 25, 4476-4485. doi: 10.1096/fj.11-191007

Wallrapp, A., Riesenfeld, S. J., Burkett, P. R., Abdulnour, R. E., Nyman, J., Dionne, D., et al. (2017). The neuropeptide NMU amplifies ILC2-driven allergic lung inflammation. Nature 549, 351-356. doi: 10.1038/nature24029

Wan, H., and Chen, Y. (2010). Effects of antidepressive treatment of Saint John's wort extract related to autonomic nervous function in women with irritable bowel syndrome. Int. J. Psychiatry Med. 40, 45-56. doi: 10.2190/pm.40.1.d

Wang, L., Zhi, X., Zhang, Q., Wei, S., Li, Z., Zhou, J., et al. (2016). Muscarinic receptor M3 mediates cell proliferation induced by acetylcholine and contributes to apoptosis in gastric cancer. Tumour Biol. 37, 2105-2117. doi: 10.1007/s13277-015-4011-0

Wheatley, L. M., Urso, D., Tumas, K., Maltzman, J., Loh, E., and Levinson, A. I. (1992). Molecular evidence for the expression of nicotinic acetylcholine receptor alpha-chain in mouse thymus. J. Immunol. 148, 3105-3109.

Willemze, R. A., Welting, O., van Hamersveld, H. P., Meijer, S. L., Folgering, J., Darwinkel, H., et al. (2018). Neuronal control of experimental colitis occurs via sympathetic intestinal innervation. Neurogastroenterol. Motil. 30:13163.

Wu, N., Sun, H., Zhao, X., Zhang, Y., Tan, J., Qi, Y., et al. (2021). Map3K2-regulated intestinal stromal cells define a distinct stem cell niche. Nature 592, 606-610. doi: 10.1038/s41586-021-03283-y

Zeng, H., Li, H., Yue, M., Fan, Y., Cheng, J., Wu, X., et al. (2020). Isoprenaline protects intestinal stem cells from chemotherapy-induced damage. $\mathrm{Br} . \mathrm{J}$. Pharmacol. 177, 687-700. doi: 10.1111/bph.14883

Zhang, Y., and Li, J. (2012). Carbachol ameliorates lipopolysaccharide-induced intestinal epithelial tight junction damage by down-regulating NF-kappabeta and myosin light-chain kinase pathways. Biochem. Biophys. Res. Commun. 428, 321-326. doi: 10.1016/j.bbrc.2012.10.056

Zhou, H., Liang, H., Li, Z. F., Xiang, H., Liu, W., and Li, J. G. (2013). Vagus nerve stimulation attenuates intestinal epithelial tight junctions disruption in endotoxemic mice through alpha7 nicotinic acetylcholine receptors. Shock 40, 144-151. doi: 10.1097/shk.0b013e318299e9c0

Conflict of Interest: The authors declare that the research was conducted in the absence of any commercial or financial relationships that could be construed as a potential conflict of interest.

Copyright (c) 2021 Duan, Cai, Luan, Yang, Yang, Dong, Zeng and Shao. This is an open-access article distributed under the terms of the Creative Commons Attribution License (CC BY). The use, distribution or reproduction in other forums is permitted, provided the original author(s) and the copyright owner(s) are credited and that the original publication in this journal is cited, in accordance with accepted academic practice. No use, distribution or reproduction is permitted which does not comply with these terms. 